\title{
National Impacts and Responses to Global Challenges: Matrices of Coloniality in Globality
}

\author{
By Johannes Tsheola*
}

\begin{abstract}
In an apparent disregard of its overt quixotic promise, globality now captivates the world's imagination as if it were an end in itself. Just like the development oxymoron, the meta-narrative of globality must be suspected for privileging particular science, knowledge or wisdom over others. Inevitably, the locus of the national impacts and responses to global challenges are admittedly illusive because they are intricately embedded with the ambivalence, ambiguity and contradictions of the production and transmission of knowledge and wisdom of science, which define the power and being of domination and subordination predisposed with coloniality in globality. Equally, the ambiguity and ambivalence of the national impacts of global challenges have elicited ambiguous and ambivalent responses, reflective of a concoction of coercion with soft power concessions that are shaped and reshaped through recursive negotiations, resistance, mimicry and hybridity. To this extent, this paper argues that national impacts and responses to global challenges are inseparable from the spatio-political-economy of universally received science, knowledge and wisdom. The hegemonic solipsistic bellicose oxymoron of global capitalist economic relations of development, are outcomes of the propensity of emulation of a set of "historical anthropology of cultural confrontation, domination, reaction and innovation; hence, violence, deceit, hypocrisy and lies are the norm in the contemporary world of globality. Therefore, the search for national impacts and responses to global challenges, especially for developing countries, should necessarily be deeply ideological and philosophical. The paper presents brief South African narratives to affirm its argument.
\end{abstract}

\section{Introduction}

This paper aims to argue that the national impacts and responses to global challenges are a direct function of contemporary coloniality of being, knowledge and power. The paper shows that the complexity, ambivalence and ambiguity of the national impacts and responses to global challenges, manifest in most developing countries through reflexive developmentalism, pointing to the persistence of coloniality of domination and subordination in the present world of intense globality. To this extent, the paper argues that the search for national impacts and responses to global challenges should necessarily be ideological and philosophical. The subject of this paper is topical because sates

${ }^{*}$ Professor \& HOD, University of Limpopo, South Africa. 
are presently engaged in a virtual race to the bottom wherein they align themselves with global economic and capital interests at the expense of national societies (Desai, Maharaj \& Bond, 2011). South Africa, which was previously subjected to colonialism, has virtually come to lead the state service to global economic and capital interests in the twenty years of its democratization, as it shifted from one development trajectory to the other without attaining the promised benefits of neoliberal globality. At the dawn of its democracy, South Africa self-proclaimed its leadership of Africa's recovery and renewal, through weddedness to neoliberal globality; and, the 2014 Index of Economic Freedom rates this country at 75 out of over 178 countries (Miller, 2014). Unsurprisingly, South Africa is the only African country that has hosted FIFA Soccer World Cup, and has continued to conduct international relations as one of the self-proclaimed emerging market set to become the future engine of global growth. Drawing from South Africa's pertinent tales, this paper insinuates that contemporary globality is, as a result, imbued with paradoxes and contradictions, which are reminiscent of the ambivalence and ambiguities of coloniality of being, knowledge and power.

If it were easy to isolate and rigorously examine the national impacts and responses to global challenges, the developing world would have long cleared the hurdle of perpetual subaltern existence. The ambivalence, ambiguity and contradictions of the national impacts and responses to global challenges are embedded with the production and transmission of knowledge and wisdom of science, which is intricately dovetailed with the power and being of domination and subordination predisposed with coloniality and globality. That is, the national impacts and responses to global challenges are inseparable from the spatio-political-economy of science, which Mignolo (2003: 669) describes as 'knowledge and wisdom', wherefrom 'coloniality of power and knowledge engendered the coloniality of being'.

In an apparent disregard of its overt quixotic promise, globality now captivates the world's imagination as if it were an end in itself, wherein states are in a race to the bottom as they 'conform to and even anticipate the needs of capital for fear of being subordinated in the global economic system', at the expense of labour and whole societies (Hardt \& Negri, 2004: 279). To this extent, commitment to capitalist economic relations should be construed as 'a naïve understanding of what development entails' or ignorance of the experiences of the global South or an outright 'mental subjugation to a Western vision' (Mkandawire, 2011: 8-9). Just like the development oxymoron, the meta-narrative of globality must be suspected for privileging 'certain forms of knowledge' while denigrating others (Mkandawire, 2011: 6). The ambivalence, ambiguities and contradictions that paralyse the hegemonic global capitalist economic relations are startling; equally, the locus of the national impacts and responses to global challenges are admittedly illusive. Apparently, it is the ambiguity and ambivalence of the national impacts of global challenges that have elicited equally ambiguous and ambivalent responses, eventualities that reflect a concoction of coercion with soft power concessions that are 'shaped by negotiation and resistance' (Ndlovu-Gatsheni, 2007: 176). For Zielonka 
(2012: 503), there are present-day empires pursuing 'civilizing missions', some with evidently atrocious consequences. The present-day globality too, just like the old notorious empires, evolved through combinations of coercion, negotiations, mimicry and hybridity (Bhabha, 1994). Inevitably, contemporary national impacts of the solipsistic bellicose oxymoron of global capitalist economic relations of development are outcomes of 'the propensity and possibility of emulation' associated with 'common humanity and intelligibility' that defines externalities of impostures and national responses to collective 'historical experiences and social needs' (Mkandawire, 2011: 7). An 'atheoretical' disposition would, therefore, lead to an intellectually fatal 'immersion in local minutiae' and a 'spectre of irrelevance' (Mkandawire, 2011: 3).

Just as the colonial encounters were, contemporary national impacts and responses to global challenges are, according to Comaroff \& Comaroff's (1991: 34 cited in Ndlovu-Gatsheni, 2007: 176) phraseology, nuance fomentations of a set of 'historical anthropology of cultural confrontation ... of domination and reaction, struggle and innovation'. National impacts and responses to global challenges, just like the oxymoron of development, are not entirely 'externally imposed discourse' (Mkadawire, 2011: 1). It is, therefore, befitting to preface this paper with dispositions of matrices of globality, which survived colonialism, described through the concept of coloniality. Thus, the concept of present-day empires, with 'civilizing missions', cannot be discounted (Huggett \& Robinson, 1996; Zielonka, 2012). Ndlovu-Gatsheni (2007: 177) cites Comaroff \& Comaroff (1991: 34) thus, 'the struggles of the dominated were purely ideological for they necessarily involved an effort to control the cultural terms by which the world was ordered and power legitimised'. That is, the search for national impacts and responses to global challenges, especially for developing countries, should necessarily be deeply ideological and philosophical in order to eschew the slippages of reading-off national impacts and responses to global challenges from preconceived schema or convenient anecdotes (Mkandawire, 2011).

\section{Theorising National Impacts and Responses to Global Challenges: Matrices of Coloniality in Globality}

Maldonado-Torres (2007: 243) edifies the notion that 'as modern subjects, we breath coloniality all the time and everyday'. In contemporary globality, it has increasingly appeared that states 'must ally themselves closely with global economic interests and abide by global rules favourable to capital flows, while their societies are being asked to wait patiently for the trickle-down benefits of corporate ingenuity' (Castells cited in Alexander, 2002: 163; Desai, Maharaj \& Bond, 2011: 17). The present capitalist form of economic relations were intricately tied with and evolved through 'forms of domination and subordination that were central to maintaining colonial control' and the 
'massive colonial enterprise' (Maldonado-Torres, 2007: 243). Indeed, Huggett \& Robinson (1996: 159) make this crucial observation thus:

'... human societies evolved social and economic systems of relative complexity that allowed them both to consolidate within "natural" boundaries and simultaneously to enlarge political control over noncontiguous territory. In the process of enlargement cultures inevitably came into conflict .... (out of which).... Larger and more powerful ones steadily extended their spheres of influence and control'.

Perhaps, the search for national impacts and response to global challenges should begin with the question whether or not there are present-day empires.

Beyond being complex and paradoxical, the national impacts and responses to global challenges for developing countries, previously subjected to colonialism, are ambivalent and ambiguous. Borrowing from NdlovuGatsheni (2013: 11), it is apparent that contemporary national impacts and responses to global challenges are produced and reproduced by 'colonial matrices of power' and perpetuated by 'pedagogies and epistemologies of equilibrium' that engineer alienation. According to Maldonado-Torres (2007: 243),

'Colonialism denotes a political and economic relation in which the sovereignty of a nation or a people rests on the power of another nation, which makes such nation an empire .... (whereas) Coloniality ... refers to long-standing patterns of power that emerged as a result of colonialism, but that define culture, labour, intersubjective relations, and knowledge production well beyond the strict limits of colonial administrations'.

Consequently, symptoms of coloniality in globality are readily reinvented and described as nuance national impacts and responses to global challenges. In the present era of neo-libertarian globalisation, national impacts and responses to global challenges cannot be dissociated from the evolution of the hegemonic capitalist economic relations wherein coloniality defines 'the spatio-temporal matrix' of power, knowledge and being (Mignolo, 2003; Maldonado-Torres, 2007). Indeed, 'knowledge matters in development' (Mkandawire, 2011: 19) as it does in globality and the global capitalist economic relations. To this extent, the conception of 'coloniality in globality' is of critical significance to understanding the ambivalence, ambiguity and contradictions of contemporary national impacts and responses to global challenges.

Coloniality draws from an on-going articulation of new and old ideologies, therefore creating continuities and disjunctures, as well as implying that understanding of the contemporary national impacts and responses to global challenges should be located in the meaning underpinning 'complex historical episodes' of the relations of 'material phenomena and ideological controversies' (Marks, 1986 cited in Ndlovu-Gatsheni, 2007: 176). The national impacts and responses to global challenges are, therefore, associated with the evolution of globality itself and the global 'spatio-temporal matrices' 
of capitalist economic relations of development. Hence, Maldonado-Torres (2007: 243) posits that coloniality persists through contemporary global capitalism and that:

'it is maintained alive in books, in the criteria for academic performance, in cultural patterns, in common sense, in the selfimage of peoples, in aspirations of self, and so many other aspects of our modern experience. In a way, as modern subjects, we breath coloniality all the time and everyday'.

Occupying the seat of science, which is knowledge and wisdom, coloniality recreates patterns of negotiations, mimicry and hybridity (Bhabha, 1994) in globality which continuously pulls, as it were, the ladder underneath, thereby disrupting the processes of global capitalist economic relations of development, which are themselves an oxymoron. In this context, Bhabha's (1994) concepts of 'negotiation, mimicry and hybridity' come handy in the disposition of national impacts and responses to global challenges under the hegemonic contemporary capitalist economic relations. That is, coloniality is largely a product of unending negotiations of the dominant and the dominated, which are constructed on ambivalence, ambiguity and contradictions that reproduce 'discriminatory identities' (Bhabha, 1994; Ndlovu-Gatsheni, 2007).

The developing world is now awash with 'meta-narratives of anticolonialism and nationalism' and post-colonialism which have 'tended to obscure the nuances of colonial history and the complex' engagements of domination and subordination (Ndlovu-Gatsheni, 2007: 174). The unending adjustment and re-adjustments of development trajectories at national scale, aided by sweeping rhetoric about the binary of economic neoliberalism and political nationalism (Desai, Maharaj \& Bond, 2011), have served as one of the most unambiguous affirmation that the abolition of colonial rule did not necessarily obliterate the lived experiences thereof. Reading Bhabha's (1994) concepts of 'negotiation, mimicry and hybridity', it becomes compelling to dovetail the examination of national impacts and responses to global challenges for developing countries, which experienced colonisation, with coloniality in globality. In the present era of neo-libertarian global capitalism, the national impacts and responses to global challenges are products of endless negotiations of the superior-inferior relations, wherefrom colonial hegemony is persistently undermined and reflexively reconstructed to be ambivalent with 'slippages, excesses and contradictions' as well as 'double articulation' and 'double vision' that 'appropriated the "Other" as it visualised power' and disrupted the authority of the discourse of globality, global capitalist economic relations of development and coloniality (Ndlovu-Gatsheni, 2007: 175). According to Bhabha (1994: 89), hybridity symbolises a space in the interface, which is a product of a blending of the diverse cultures or traditions of the dominant power and the dominated. That is, coloniality in globality is equally a trail of 'ambiguous legacies of invented traditions' (Ndlovu-Gatsheni, 2007: 175). Contemporary empires too are 'highly mutable' and 'far from certain', given the 'ongoing economic and security turmoil' (Zielonka, 2012: 512). 
Developing countries have commonly experienced the worst effects of the ascendancy of neo-libertarian globality, wherein the "political and economic landscape presents a vulnerable picture' (Parsons, 2013: xv), largely because coloniality reproduces and sustains itself 'through a combination of violence, deceit, hypocrisy and lies', which are evidently the norm in the present world (Ndlovu-Gatsheni, 2013: 11). The ascendency of globality was hailed as the dawn of a new world order of interdependence and mutual benefit, rather than disorder of domination, extraversion and subjugation. However, it has now become increasingly apparent that neoliberal globality involves subverted continuities of the processes and legacies of slavery, imperialism, colonialism and neo-colonial capitalism, wherein coditian experiences of coloniality of being, power and knowledge are reinvented through nuance matrices (Grosfoguel, 2007; Maldonado-Torres, 2007; Ndlovu-Gatsheni, 2007, 2013; Gordon, 2011; Zielonka, 2012).

Therefore, the concept of coloniality describes the collective contemporary national impacts and lived experiences drawing from a myriad of processes, including legacies of slavery, imperialism, colonialism, domination, global capitalism, neo-colonialism, neoliberalism and globalisation (Grosfoguel, 2007; Ndlovu-Gatsheni, 2007, 2013; Maldonado-Torres, 2007; Gordon, 2011). Developing countries' progress and development under neo-libertarian globality has involved complex processes of 'intentionality' and 'purposefulness' which, however, did not destroy coloniality of being, power and knowledge for former colonies (Grosfoguel, 2007; Maldonado-Torres, 2007; Ndlovu-Gatsheni, 2007, 2013; Gordon, 2011; Mkandawire, 2011). If the slippery buzzwords of globalisation is itself a determinant of progress and development, the apparent failure of the developing world to succeed should raise questions of its universal replicability as well as the desirability of its 'developmental' oxymoron as societal vision (Mkandawire, 2011). As a result of the hype associated with the ascendency of globality, the attendant coloniality came to be virtually normalised and universalised as 'a natural state of the world' (Ndlovu-Gatsheni, 2013: 11). Hence, global spatio-political inequalities have persisted historically.

The "development" oxymoron has almost always been met with suspicions in the developing world, especially in Africa where it has been captured in phrases such as the myth, the impasse or the crisis of development, 'the rise and fall of development', 'post-development', disaster of social engineering, dustbin of history, accession to Western superiority, denigration of local knowledge and innovation, and a repressive meta-narrative that made for privilege of those defined to hold merit and oppression of those recognised as enthroning mediocrity (Mkandawire, 2011: 5). In the present era, therefore, the historicity of development involves complex matrices of slavery, colonialism, global capitalism, state capitalism, neoliberalism and globalisation whose impacts are organised at the local scale of everyday life through principles of race, gender, ethnicity (Grosfoguel, 2007; Maldonado-Torres, 2007; NdlovuGatsheni, 2007, 2013; Gordon, 2011; Mkandawire, 2011) as well as the 'homogenising thrust' and 'compulsions of the market' that are 'rechristened as 
globalisation' where 'emulation is a consequence of all human exchange' (Mkandawire, 2011: 5).

The fundamental challenge that developing countries are confronted with in the era of neo-libertarian globality is in the lack of nuance and usable science (knowledge and wisdom) that could be applied in the struggles to confront, unmask, resist and destroy coloniality. To this extent, this paper postulates that the many impediments that are identified in global commodity prices, food insecurity, deficit in the balance of trade (payments), shortfall in the current account, capital flight, unfair and unequal trade, developed world's selective protectionism, restricted access to developed markets, lack of capacity, inadequately skilled labour force, corruption, tyrant rulers, despot regimes, failed states, nominal fundraising regionalism, global openness and the global financial crisis, are symptoms of the underlying matrices of coloniality of being, knowledge and power. The vogue of misrepresentation of national impacts and responses to global challenges is more pronounced for Africa where states, countries and elites have been variously described as 'venal', 'prebendal', 'overdeveloped', 'dependent', 'rentier', 'vampire', 'petty bourgeois', 'neo-colonial', 'neo-patrimonial' and 'gatekeeper' state (Mkandawire, 2011: 21). Where attempts are made to engender economic freedom policies such as in South Africa, which is rated 75 on the 2014 Index of Economic Freedom (Miller, 2014), accusations of 'crony capitalism and tenderpreneurship' (Desai, Maharaj \& Bond, 2011) are abound. But these and such other descriptors fail to provide analytical tools for the production of appropriate and usable science, knowledge and wisdom for amelioration of deleterious national impacts, and enhancement of responses to global challenges.

The reality of the present globality is that notions of post-colonialism and postapartheidism are illusions. It is imperative that the on-going national impacts and responses to global challenges be analysed in the context of the matrices of coloniality that have been sustained through neo-libertarian globality. Evidence to this reality is in the widespread nature of official state violence, deceit, brutality, hypocrisy and lies, amidst public pronouncements and provisions for liberal democratic principles. The brutal and fatal state violence against miners in August 2012 in Marikana, South Africa, is a vivid manifestation of national impacts and responses to global challenges wherein politics, business and statism coalesce to serve the interests of private multinational companies at the expense of the disenfranchised citizenry and at the risk of fomenting social strive. South Africa presents interesting illustrations of the ambivalence, ambiguous and paradoxical national impacts and responses to global challenges.

\section{Democratic South Africa: Coloniality and Paradoxes of Impacts and Responses to Global Challenges}

The reality in developing countries such as South Africa, previously subjected to colonialism, is that symptoms of national impacts and responses to global challenges manifest in overt differences in unemployment, poverty, disease, pandemic, hunger, crime and so on, codified through 'the idea of race 
... that placed some in a natural situation of inferiority to the others' (Quijano, 2000: 533 cited in Maldonado-Torres, 2007: 243). The developing world and Africa are not innately paradoxical, ambivalent or ambiguous. Understanding of the national impacts and responses to global challenges yawns, therefore, for rigorous examination of the strictures and matrices of coloniality in the hegemonic global capitalist economic relations. The latter circumvents the potential for nuance and fresh national development trajectories, thereby endorsing reinvention of variants of state capitalism in recurrent reflexivity. Analysis of national impacts and responses to global challenges for developing countries that were previously subjected to colonialism will reveal globality's deep-seated ambivalence, ambiguities and paradoxes.

In a two-year span, South Africa successfully hosted the FIFA Soccer World Cup, only to enter a downward spiral in 2012 (Parsons, 2013). Parsons' (2013: xiv) predisposition is that as the global situation deteriorated the margin for error in domestic policy also shrank. However, the truth is more disconcerting; and, Desai, Maharaj \& Bond (2011: 33) use the FIFA Soccer World Cup to eloquently point to the core problem of contemporary globality, thus:

'Yet capitalist hegemony as reflected in commodification, corporate power and periodic displays of state repression, all displayed prominently in mid-2010, is bound to decline, in part because so many aspects of poverty and inequality - amplified as they were by the World Cup, its preparations and its aftermath - will be looked back upon as a collective Own Goal by South Africans. The tragedy, of course, is that this was a time when a very different outcome to the game was possible had the players in Pretoria stayed and fought onside with their constituents, not wandered offside with capital'.

During the last quarter of the $20^{\text {th }}$ century and the first two decades of the $21^{\text {st }}$, all manner of prescriptions that are touted as 'new' have uniformly been 'circumscribed by the prevailing circumstances' (Mkandawire, 2011: 6), prompting insinuations that 'nothing works' for developing countries, in general, and for Africa, in particular. Increasingly, cumulative evidence demonstrate that global progress associated with neoliberal globality has, for the developing world, historically undermined the narratives of emancipation whilst their so-called development was devoid of societal self-responses to own 'historical experiences and social needs' as well as self-discovery (Mkandawire, 2011: 7). Inevitably, developing countries face a myriad of global challenges that appear, on the face of it, intractable, especially for those that were previously subjected to colonialism. There could be no perfect reflection of the paradoxes of marriage to neo-libertarian globality than a democratic South Africa's virtual insertion and extraversion in its race for glory of hosting the Soccer World Cup. To accommodate FIFA's interests, which may not coincide with those of the national publics, South Africa borrowed momentous funds to construct first world road infrastructure, which has now necessitated the most contested e-tolling of freeways in Gauteng Province. Parsons (2013: xv) is surprised that South Africa which successfully 
hosted the 2010 FIFA Soccer World Cup, came to receive negative ratings in The Economist, that it was sliding downhill while much of the rest of Africa is clawing its way upwards. In truth, there should be no surprises because the manifestations of national impacts and responses to global challenges for developing countries that were previously subjected to colonialism can be perfectly anticipated. ESKOM, a South African energy utility has recently revealed that it had arranged excessively low electricity rates for the mining multinational giant BHP Billiton when the publics paid more than five times that rate.

Parsons (2013: xvi) cites an old business adage that 'planning without action is futile, action without planning is fatal', which provides a relevant description of developing countries' position in relation to national impacts and responses to global challenges. Developing countries, especially those that were subjected to colonialism in Africa, are presently over-planned. Africa has seen a complex myriad of plans that are scarcely implemented, amidst ad hoc action on a variety of fronts. South Africa provides a refreshing example of taking action that was not in the Grand National Plan, as in ceding membership of the BRICS. Only now, the BRICS is searching for its founding vision. Besides, South Africa has devised innumerable plans in a period of just 20 years; yet, the deleterious national impacts of global challenges have remained intractable. Inevitably, on-going attempts for redress are trapped in the coloniality of being, power and knowledge. At the continental scale, the New Partnership for Africa's Development (NEPAD) has been neither 'new' nor African-grown. The same observation is pertinent to national experiences of the recently 'democratised' South Africa which, in its aspiration for engaging globalisation for domestic development, flirted with the Reconstruction and Development Programme (RDP), Growth, Employment and Redistribution (GEAR), Accelerated and Shared Growth in South Africa (AsgiSA), New Growth Path and, now, the National Development Plan (NDP) 2030. Indeed, South Africa's 20 year life story is riddled with plans that were barely allowed time for their implementation and maturation. Following the 1994 Reconstruction and Development Programme, the 1996 Growth, Employment and Redistribution was overshadowed by the 2006 Accelerated and Shared Growth in South Africa, which was itself tempered with the 2010 New Growth Path and then the presently contested 2012 National Development Plan 2030 Vision (Mbeki, 2009; Alloggio \& Thomas, 2013; Biko, 2013; Habib, 2013). Inevitably, these plans have involved more continuities than discontinuities. But Parsons (2013: xvi) argues that 'both the publication of the New Growth Path in 2010 and that of the subsequent, more holistic National Development Plan in 2012 have demonstrated how new elements can enter into the public arena of discussion and action'. However, the persistence of poverty and inequality presents indisputable proof that the so-called plans are reflexive hybridities of emulation.

The most common denominator over the past 20 years for South Africa is that its marriage to neo-libertarian globality has remained strongly associated 
with persistent poverty, increased beneficiaries of social assistance dependence, highly skewed distribution of national income and exposure of the domestic economic structure of production to harsh global elements. South Africa's NDP 2030 identifies unemployment, poverty and lack of social cohesion as key challenges (National Planning Commission, 2012). This paper argues that these eventualities are at heart manifestations of a concoction of externalities and the national states' self-selection as well as avoidance of transformation and struggle for the destruction of coloniality. That is, developing countries such as South Africa that were previously subjected to colonial rule have continued to be extraverted as subordinates under the ascendency of neo-libertarian globality. Such countries have responded to the imposture of neo-libertarianism by establishing state capitalism, wherein the visible hand of the state supplements the invisible hand of the market (Glemarec \& Puppim de Oliveira, 2012; Tsheola, 2013).

China's 'Red Capitalism' and, to a limited extent, India's 'capindialism' has inspired most of the developing economies to adopt state capitalism as a response to the national impacts of global challenges associated with the capitalist economic relations of development. In essence, state capitalism allows for the use of state power to supplement the market mechanisms. The core ingredient of state capitalism is the new hybrid of state-owned enterprises, which have re-emerged to dominate the global business stage. Some of these SOEs, whereas established through public policy objectives, have become more powerful than their funder-states; and, they have incrementally sought for more autonomy under the illusionary guise that state ownership and control imperil commercial financial progress. To this extent, state capitalism which is not tempered with a strong government regime was always destined to fail to replicate China's successful combination of capitalism and state control. State capitalism for most developing countries that were previously subjected to colonialism has eventually allowed a free-marketer takeover of the national political-economy space, wherein political leaders abrogate their public mandate through intractable business entrapments with capitalism, commonly described as 'bureaugarchs'. Unavoidably, liberal democracies have increasingly become synonymous with state violence, brutality, deceit, hypocrisy and lies. South Africa's NDP 2030 Vision too is wedded to neoliberal capitalism and globality, wherein coloniality of being, knowledge and power continues to reign supreme.

\section{Conclusion}

The contention of this paper is that impacts and response to global challenges are at a national scale, complex, paradoxical, ambivalent, ambiguous and protracted, in the same way as the oxymoron of global capitalist economic relations of development is. Global capitalism operates through unfair markets, as well as speculation on stock exchanges, currency and futures markets (Peet, 2002; Orrell, 2010). Notwithstanding the global recognition of the power of emerging markets within the evolving global 
governance structures, their role in the international system has remained inconsequential (Cooper, 2009). The paper concedes that developing countries have, rather than confront the evils of the impacts of global challenges, deferred the necessary struggles of decoloniality because of the inherent ambivalence, ambiguity and paradoxes of contemporary globality. It is evident that countries, especially the developing ones that were previously subjugated to colonialism, have not as yet embarked on 'radical rethinking of institutions of collective response to the many challenges about the generation and mastery of ... knowledge' (Mkandawire, 2011: 1). For those developing countries that were previously subjugated to colonial rule, a grim situation of development dilemmas and paradoxes has coerced them into unfettered extraversion and subjugation in the hope of maximising benefits of globality and the global capitalist economic relations.

The most critical question to be asked is how a country that was previously subjected to colonialism has to extricate itself from the coloniality of being, existence, knowledge and power? Unfortunately, there are no historical intellectual pathways that the developing world could slavishly and teleologically emulate, because the development oxymoron of societal vision is a paradoxically blared process of 'groping in the dark' (Mkandawire, 2011). The key global challenge for developing countries is, therefore, in their being and paradoxical responses that are pre-circumscribed through matrices of coloniality in globality. Desai, Maharaj \& Bond (2011: 2) make a compelling observation regarding a democratic South Africa's state of intellectual sloth, thus:

'Most academics took on consultancies to become more relevant, and in such a milieu, asking bigger questions about the mode of production is painly useless. The resulting state of intellectual sloth has compelled us to ask, both in our practice and our thought: are we uprooting or rerooting poverty in post-apartheid South Africa?'

To succeed, developing countries should individually chart nuance pathways of self-discovery. In the same way that 'the sovereignty of the lost "Self" of the colonies cannot be restored, .... the long-term historical and cultural effects of colonialism are irreversible' (Spivak, 1994 cited in NdlovuGatsheni, 2007: 176). The fate of states is, in the face of national impacts and responses to global challenges, similarly predetermined, circumvented and compromised through the 'coloniality in globality'.

\section{References}

Alexander, N. (2002). An ordinary country. Pietermaritzburg: University of Kwa-Zulu Natal.

Alloggio, S. \& K. Thomas (2013). 'Resisting the lure of deferral: realising the South African National Development Plan.' Social Dynamics: A Journal of African Studies 39(1): 108-110.

Bhadha, H. (1994). The location of culture. London: Routledge. 
Vol. 1, No. 2 Tsheola: National Impacts and Responses to Global Challenges...

Biko, H. 2013. The great African society: A plan for a nation gone astray. Johannesburg: Jonathan Ball.

Cooper, A.F. (2009). 'Picking your club: G8 or G20, BRICs or B(R)ICSAM?' Keynote Presentation for Oxfam International at the BRICSAM and the Fight against Global Poverty, July 13 , in Geneva.

Desai, A., B. Maharaj \& P. Bond (2011). 'Introduction: Poverty eradication as Holy Grail.' In: B. Maharaj, A. Desai \& P. Bond (eds.), Zuma's own goal: Losing South Africa's 'War on Poverty', 1-35. Trenton: Africa World Press, Inc.

Glemarec, Y. \& J.A. Puppim de Oliveira (2012). 'The role of the visible hand of public institutions in creating a sustainable future.' Public Administration and Development 32: $200-214$.

Grosfoguel, R. (2007). 'The epistemic decolonial turn.' Cultural Studies 21(2-3): 211-223.

Habib, A. (2013). South Africa's suspended revolution: Hopes and prospects. Johannesburg: Wits University Press.

Hardt, M. \& A. Negri (2004). Multitude. New York: Penguin.

Huggett, R. \& M. Robinson (1996). 'Introduction.' In: I. Douglass, R. Huggett \& M. Robinson (eds.), Companion encyclopedia of geography: The environment and humankind, 159-161. London: Routledge

Maldonado-Torres, N. (2007). 'On the coloniality of being.' Cultural Studies 21(2-3): 240270.

Mbeki, M. (2009). Architects of poverty: Why African capitalism needs changing. Johannesburg: Picador Africa.

Mignolo, W. (2003). The darker side of the renaissance: Literacy, territoriality, and colonisation. $2^{\text {nd }}$ ed. Ann Arbor: The University of Michigan Press.

Miller, T. (2014). 'America's dwindling economic freedom: regulation, taxes and debt knock the U.S. out of the world's top 10.' Wall Street Journal, (January):n.p.

Mkandawire, T. (2011). 'Running while others walk: knowledge and the challenge of Africa's development.' Africa Development 36(2): 1-36.

National Planning Commission (NPC.) (2012). National Development Plan 2030: Our future-Make it work. Pretoria: The Presidency.

Ndlovu-Gatsheni, S.J. (2007). 'Re-thinking the colonial encounter in Zimbabwe in the early twentieth century.' Journal of Southern African Studies 33(1): 173-191.

Ndlovu-Gatsheni, S.J. (2013). 'Why decoloniality in the $21^{\text {st }}$ century?' The Thinkers 48 : 10 15.

Orrell, D. (2010). Economyths: Ten ways that economics gets it wrong. London: Icon Books.

Parsons, R. (2013). ZUMANOMICS revisited: The road from Mangaung to 2030. Sunnyside: Jacana.

Peet, R. (2002). 'Ideology, discourse, and the geography of hegemony: from socialist to neoliberal development in post-apartheid South Africa.' Antipode 34(1): 54-84.

Tsheola, J. (2013). 'State capitalism meta-governance, state-capital nexus and state activism paradoxes in the Gauteng Freeways.' Journal of Public Administration 48(1): 35-50.

Tsheola, J.P., M.D. Ledwaba \& P. Nembambula (2013). 'State-owned enterprises on the global business stage: Whither the South African owner-publics?' Politeia: South African Journal for Political Science \& Public Administration 32(2): 20-36.

Zielonka, J. (2012). 'Empires and the modern international system.' Geopolitics 17(3): 502525 . 